\title{
Hydrothermal system in the Tatun Volcano Group, northern Taiwan, inferred from crustal resistivity structure by audio-magnetotellurics
}

\author{
Shogo Komori ${ }^{1,6 *}$, Mitsuru Utsugi ${ }^{2}$, Tsuneomi Kagiyama ${ }^{2}$, Hiroyuki Inoue ${ }^{2}$, Chang-Hwa Chen ${ }^{1}$, \\ Hsieh-Tang Chiang ${ }^{3}$, Benjamin Fong Chao ${ }^{1}$, Ryokei Yoshimura ${ }^{4}$ and Wataru Kanda ${ }^{5}$
}

\begin{abstract}
The present study proposes an improved conceptual model for the hydrothermal system in the Tatun Volcano Group in northern Taiwan. In the study, audio-magnetotellurics (AMT) surveys were conducted to reveal the spatial distribution of resistivity, which is highly sensitive to fluids and hydrothermal alteration. By combining the obtained resistivity structure with other geophysical and geochemical evidence, the following hydrothermal system was inferred. Beneath Chishinshan, vapor-dominant hydrothermal fluids, supplied from a deeper part, are maintained in a low to relatively low resistivity region ( 5 to $20 \Omega \mathrm{m}$ ) that is covered by a clay-rich cap, represented by an upper extremely low resistivity layer. Fluid ascent is suggested by a pressure source and clustered seismicity. Exsolved gases result in fumarolic areas, such as Siao-you-keng, while mixing of gases with shallow groundwater forms a shallow flow system of hydrothermal fluids in the Matsao area, represented by a region of less than $10 \Omega \mathrm{m}$. The fumarole in the Da-you-keng area originates from vapor-dominant hydrothermal fluids that may be supplied from a deeper part beneath Cing-tian-gang, suggested by a pressure source and low to relatively low resistivity. Horizontally extended vapor-bearing regions also suggest the possibility of future phreatic eruptions. The proposed conceptual model may provide clues to detecting precursors of potential volcanic activity.
\end{abstract}

Keywords: Tatun Volcano Group; Hydrothermal system; Resistivity; Vapor-dominant region; Pressure sources; Gas and groundwater geochemistry

\section{Background}

The Tatun Volcano Group (TVG) covers an area of approximately $300 \mathrm{~km}^{2}$ on the northern tip of the island of Taiwan, only about $10 \mathrm{~km}$ north of the capital city of Taipei. The group is composed of over 20 andesitic volcanic composites, cones, and domes (Chen and $\mathrm{Wu}$ 1971; Wang and Chen 1990), enclosed by NE-SW trending faults such as the Chinshan and Kanchiao faults, as shown in Figure 1. The magmatism of the TVG is considered to have taken place in an extensional stress field, which was associated with postcollisional processes between the Philippine Sea Plate and East Asian continent, and with

\footnotetext{
${ }^{*}$ Correspondence: komori.shogo@aist.go.jp

${ }^{1}$ Institute of Earth Sciences, Academia Sinica, 128 Academia Road, Section 2, Nankang, Taipei 115, Taiwan

6 Present address: Geological Survey of Japan (GSJ), AIST, Central 7, 1-1-1

Higashi, Tsukuba, Ibaraki 305-8567, Japan

Full list of author information is available at the end of the article
}

the opening of the southwestern end of the Okinawa Trough (Wang et al. 1999; Chang et al. 2003; Shyu et al. 2005; Chen et al. 2010). A look at historical volcanic eruptions has suggested that volcanism has been extinct since the last major activity that occurred from 0.8 to $0.2 \mathrm{Ma}$ BP (e.g., Juang 1993; Tsao 1994). However, recent studies offer suggestions that the potential for volcanic activity exists in the area: extensive hydrothermal activity is discharging a large amount of heat (e.g., Chen 1970); there are strongly acidic hot springs ( $\mathrm{pH}$ approximately 1 to 3 ) (e.g., Liu et al. 2011; Ohsawa et al. 2013); magmatic contributions are found in fumarolic gases (e.g., Yang et al. 1999, 2003; Lee et al. 2005; Ohba et al. 2010); relatively young ejecta can be observed ( $<20 \mathrm{ka}$, Chen and Lin 2002; $6 \mathrm{ka}$, Belousov et al. 2010), and the presence of clustered seismicity and shallow pressure sources suggest fluid flows (Lin et al. 2005; Konstantinou et al. 2007, 2009; Murase

\section{量 Springer}

(c) 2014 Komori et al: licensee Springer. This is an Open Access article distributed under the terms of the Creative Commons Attribution License (http://creativecommons.org/licenses/by/4.0), which permits unrestricted use, distribution, and reproduction in any medium, provided the original work is properly credited. 


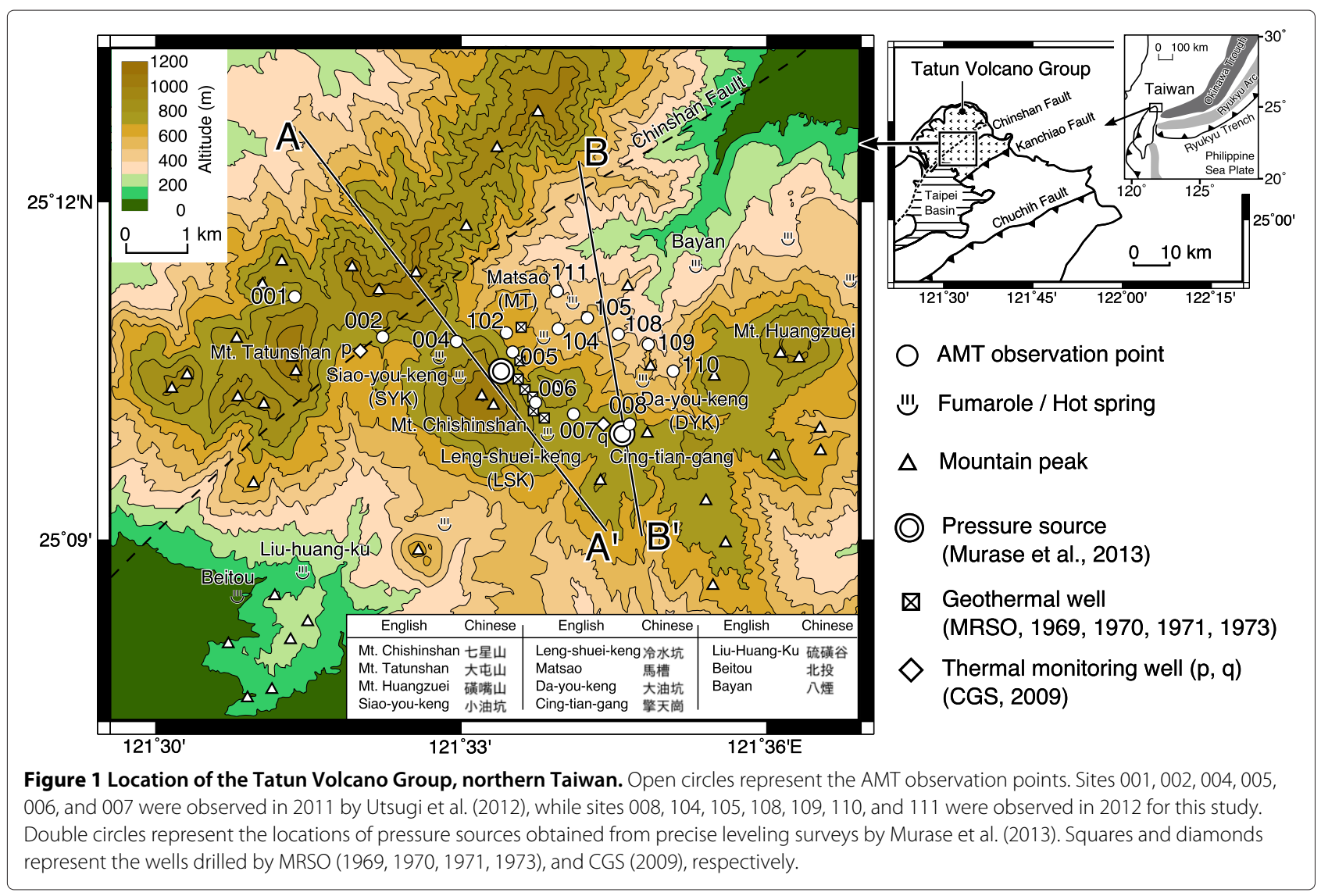

et al. 2013). Based on the above studies, hazard assessments and monitoring projects are being conducted (e.g., Lee et al. 2008; Wu et al. 2009; Tsai et al. 2010; Lin et al. 2012; Rontogianni et al. 2012).

Electric resistivity is one useful physical parameter for exploring the nature of a hydrothermal system because of its great sensitivity to the existence of fluid and hydrothermal alteration. In general, bulk resistivity decreases with increases in pore water connectivity, saturation, salinity, temperature, and smectite content due to rock alteration (e.g., Revil et al. 1998, 2002; Waxman and Smits 1968). Many studies to date have found resistivity anomalies corresponding to the paths and phase states of hydrothermal fluids, and to the fluid-bearing structure in volcanic and geothermal areas (e.g., Ogawa et al. 1998; Kanda et al. 2008; Aizawa et al. 2009; Komori et al. 2010, 2013a; Revil et al. 2011). Therefore, resistivity anomalies may provide critical constraints leading to better models of hydrothermal systems. The present study proposes an integrated hydrothermal model that combines newly revealed electric resistivity structures of the crust with geophysical and geochemical evidence. We discuss implications for potential future phreatic eruptions for the TVG.

\section{Methods and Results AMT surveys}

\section{Electromagnetic studies at the TVG}

The magnetotellurics (MT) principle (e.g., Cagniard 1953; Vozoff 1991; Simpson and Bahr 2005) is based on electromagnetic induction and has been widely used at hydrothermal and volcanic areas for estimating the crustal electric resistivity structures associated with their activity. MT was first used by Chen et al. (1998) and Chen 2009 in the TVG to provide preliminary 1-D and 2-D structures, respectively. In addition, Kagiyama et al. (2010) conducted extensive and dense VLF-MT surveys to investigate resistivity features near the surface using a singular electromagnetic frequency of $22.1 \mathrm{kHz}$. They found low resistivity anomalies (less than $30 \Omega \mathrm{m}$ ) corresponding to the fumarole and hot spring areas. Their NE-SW trending distributions suggested that the hydrothermal activity might be controlled by polarized permeable paths developed in response to the regional stress field (Chang et al. 2003; Shyu et al. 2005; Chen et al. 2010). Utsugi et al. (2012) conducted dense audio magnetotellurics (AMT) surveys around Mt. Chishinshan to reveal a resistivity structure down to depths of 2-3 km using multiple frequencies of $1 \mathrm{~Hz}$ to $10 \mathrm{kHz}$. This study extended the 
AMT observation points to the Matsao and Da-you-keng areas to the north, where there are also active fumaroles and hot springs (Figure 1). The present study will show the shallow crustal resistivity structure associated with the intense hydrothermal activity in the TVG in northern Taiwan. Incorporating the data from Utsugi et al. (2012), we will propose an integrated model of detailed crustal resistivity structures, particularly beneath Mt. Chishinshan, and the Matsao hot spring and Da-you-keng fumarolic areas.

It is notable that in the late 1960 s to early 1970 s, the Mining Research and Service Organization (MRSO 1969, 1970, 1971, 1973) conducted extensive electrical resistivity surveys (DC surveys) to obtain the spatial distribution of apparent resistivity in the TVG for the purpose of commercial use of its geothermal energy. Unfortunately, at that time, the detailed resistivity structure could not be revealed because of a lack of inversion techniques and insufficient sounding depths.

\section{Data acquisition and processing}

AMT surveys were conducted in October 2011 by Utsugi et al. (2012), and in December 2012 for the present study, using two Phoenix Geophysics MTU-5 systems. AMT pre-surveys began in 2010. There was no significant change in volcanic activity in the TVG during the time (e.g., Murase et al. 2013; Wen et al. 2013). Figure 1 shows the observation points. Those used in 2011 and 2012 were configured to intersect Mt. Chishinshan and the Matsao hot spring and Da-you-keng fumarolic areas. Four $\mathrm{Pb}-\mathrm{PbCl}_{2}$ electrodes were used to measure two orthogonal components (N-S and E-W) of the electric field, and one additional electrode was used for grounding. Three orthogonal components (N-S, E-W, and vertical) of the magnetic field were measured using three induction coils. Each consisted of a coil of copper wire wound on a core with high magnetic permeability. At each observation point, continuous data acquisition was carried out for about $4 \mathrm{~h}$. To remove contamination in the data due to local noise, we used Gamble et al.s (1979) remote reference processing method for mutual referencing within the survey area. Actually, there are noise sources like power lines and inhabited areas around the study area that seriously affected the data even after removing the noise as described above. For this study, we removed any data whose electric and magnetic fields had a coherence of less than 0.7 to maintain high quality.

\section{Dimensionality}

To examine the regional dimensionality of this study area, impedance phase tensors and skew angles $(\beta)$ were calculated using the method of Caldwell et al. (2004); this method has the merit of removing distortions from original impedances due to near-surface heterogeneities. Figure 2a shows the impedance phase tensors, skew angles, and induction arrows for representative frequencies.

Skew angle $\beta$ is a proxy for three-dimensional (3-D) heterogeneity in the media structure, where larger $\beta$ values mean stronger effects. The $\beta$ value tends to gradually increase with decreasing frequencies. In particular, relatively larger average $\beta$ values were estimated at observation points near Mt. Chishinshan. Uncertainties were less than $0.1^{\circ}$ for 100 to $10,800 \mathrm{~Hz}$ and less than a few degrees for 1 to $100 \mathrm{~Hz}$. The resulting values were a few degrees in the range of several hertz to several hundred hertz, suggesting a relatively minor 3-D effect. In addition, the average $\beta$ at the same frequencies is as small as $0.5^{\circ}$ to $2^{\circ}$ at the observation points off Mt. Chishinshan, so it is reasonable to infer that 3-D heterogeneity has a minor effect on a regional scale. It is also notable that the average $\lambda$ values calculated using the magnitudes of the principal axes of phase tensor ellipses, which are the proxy for the one-dimensional (1-D) structure (Bibby et al. 2005), were found to be as small as 0.2 to 0.3 , suggesting a relatively simple structure beneath the observation sites.

\section{Strike estimation}

The direction of the main axes of the phase tensor ellipses reflect a two-dimensional (2-D) strike (Caldwell et al. 2004). In order to estimate the regional strike, we focused on the data at lower frequencies. The tensor ellipses at frequencies of 18.8 and $8.1 \mathrm{~Hz}$, shown in Figure 2a, have the following features. Most have main axes trending NW-SE at observation points around Mt. Chishinshan (sites 001, 002, 004, 102, 007) and in the Matsao area (sites 111, 104, 105). Those in the Da-you-keng area (sites 108, 109, 110, 008), however, have main axes in the N-S direction. Thus, we defined three areas, referred to as the Chishinshan, Matsao, and Da-you-keng areas, to estimate the respective direction of the major axes. Note that point 102 was at the intersect and was used in both the Chishinshan and Matsao areas.

Figure $2 \mathrm{~b}$ shows the rose diagrams of the main axes of the phase tensor ellipses for each area. Uncertainties were lower than a few degrees for 100 to $10,800 \mathrm{~Hz}$, and up to $10^{\circ}$ for 1 to $100 \mathrm{~Hz}$. The rose diagrams are rendered in discrete frequencies; this is because there are insufficient data at $530 \mathrm{~Hz}$ to $3.6 \mathrm{kHz}$ and 40 to $79 \mathrm{~Hz}$ (460 Hz to $3.6 \mathrm{kHz}, 16.2$ to $116 \mathrm{~Hz}$, and 1 to $6.9 \mathrm{~Hz}$ for the Chishinshan area). According to Caldwell et al. (2004), the dominant direction of the main axes of the phase tensor ellipses reflects the direction of either a regional strike or a conductivity discontinuity. They note that the obtained direction has a $90^{\circ}$ ambiguity. The dominant directions of the main axes were estimated primarily 
(a)
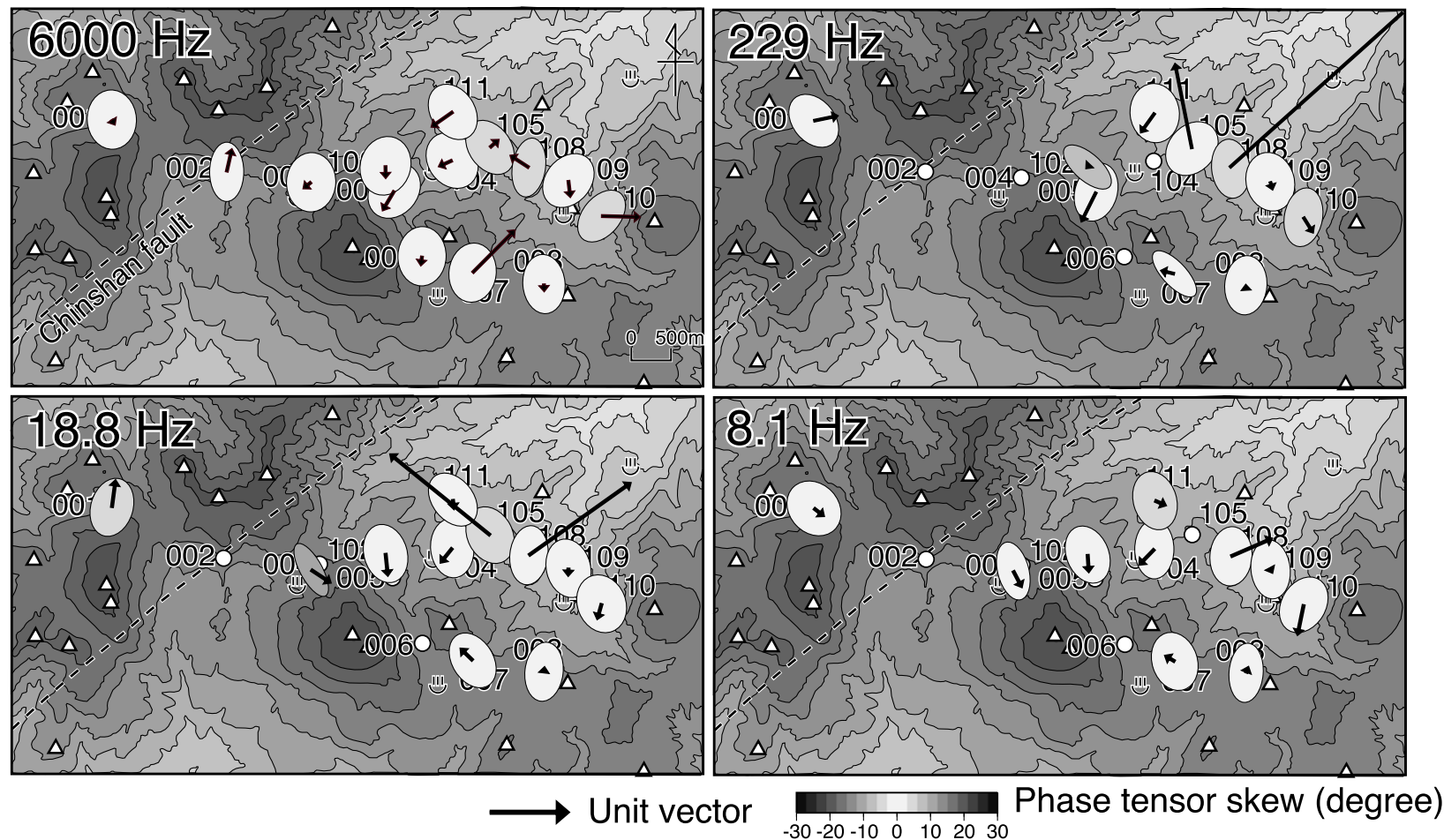

(b) Chishinshan area
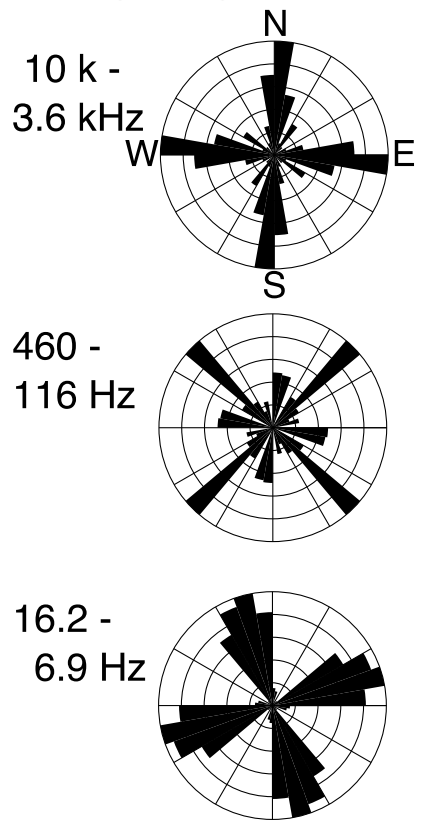
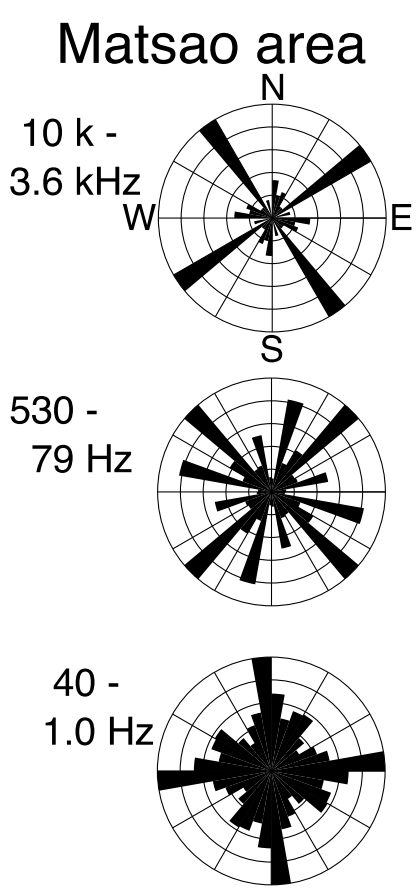

Da-you-keng area
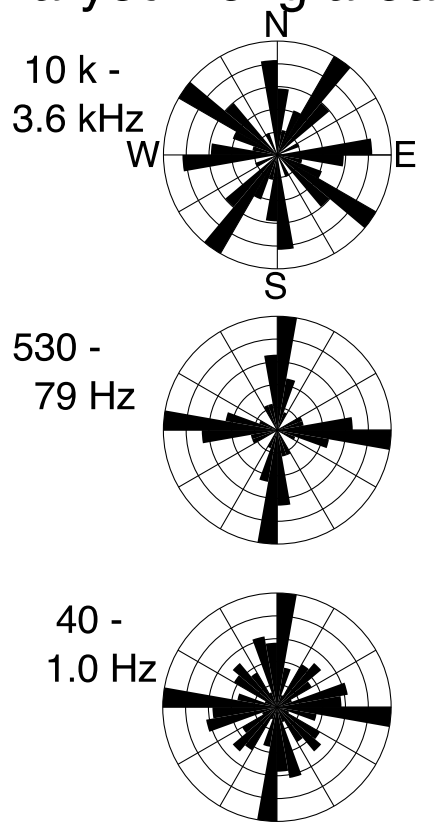

Figure 2 Data for dimensionality and strike estimation. (a) Impedance phase tensors, skew angles $\beta$, and induction arrows for representative frequencies. Note that some data are missing due to their low quality. Also note that the larger induction vectors observed at sites 007, 105, and 108 are considered to be due to noise, as these sites are located near electrical cables and roadways. (b) Rose diagrams of tensor axes. 
from their modes in each area. The rose diagrams at several to several hundred hertz show that there are two rough types of dominant directions: NW-SE (or NE-SW) in the Chishinshan area and N-S (or E-W) at the Da-youkeng area, with the Matsao area having an intermediate direction.

As described above, northern Taiwan has regional NE$\mathrm{SW}$ trending faults (approximately $\mathrm{N} 60^{\circ} \mathrm{E}$ ). Correspondingly, a NE-SW volcanic trend has developed along the Chinshan fault (e.g., Belousov et al. 2010). The TVG also has an E-W volcanic trend from Mt. Huangzuei to Mt. Tatunshan (Belousov et al. 2010), suggesting a weak extra E-W trending structure. The structural features noted above are consistent with the dominant directions of the main axes of the phase tensor ellipses. The induction vectors also trend roughly NW-SE and N-S in the Mt. Chishinshan and Da-you-keng areas, respectively, which suggests that the regional strike is perpendicular to the induction vector in each area. Based on these factors, the regional strike was estimated using the dominant directions at low- to middle-frequency ranges (below several hundred $\mathrm{Hz}$ ) as follows: $\mathrm{N} 57^{\circ} \mathrm{E}$ for the Chishinshan area, $\mathrm{N} 65^{\circ} \mathrm{E}$ for the Matsao area, and and $\mathrm{N} 85^{\circ} \mathrm{W}$ for the Dayou-keng area. This means that the 2-D cross sections are along $\mathrm{N} 33^{\circ} \mathrm{W}$ for the Chishinshan area (line A-A' in Figure 1), $\mathrm{N} 25^{\circ} \mathrm{W}$ for the Matsao Matsao area, and $\mathrm{N} 5^{\circ}$ E for the Da-you-keng area. The 2-D cross section of the Matsao area is close to that of the Da-you-keng area, so we combined the Matsao and Da-you-keng areas into one and assumed its $2-\mathrm{D}$ cross section as $\mathrm{N} 10^{\circ} \mathrm{W}$ (Line B-B' in Figure 1).

Accordingly, we rotated the impedance tensors to correspond to 2-D strikes oriented to $\mathrm{N} 57^{\circ} \mathrm{E}$ for the Chishinshan area and $\mathrm{N} 80^{\circ} \mathrm{E}$ for the Matsao-Da-you-keng area. We then performed a distortion analysis following the method of Bibby et al. (2005). This procedure estimates a distortion tensor, produced by surface heterogeneity, considering the ellipticity of a phase tensor and $\beta$ angle. The effect of the distortion was removed from the rotated impedance tensor by multiplying the inversion matrix of the distortion tensor with the impedance tensor.

\section{Soundings}

Figure 3 shows the sounding curves of the apparent resistivity and phase, with open circles representing the TE mode and open rhombi for the TM mode, calculated from the impedance tensors as described above. The apparent resistivity and phase of the TM mode were calculated using electric fields perpendicular to the strike and magnetic fields parallel to the strike and the opposite for the TE-mode. For both modes, apparent resistivities have high values at high frequencies throughout and decrease with decreasing frequencies. In general, the apparent resistivity decreases with decreasing frequency for both modes.

Sounding observations at Chishinshan area, shown in Figure 3a, have the following features. Site 001 has phases less than $45^{\circ}$ in high-frequency ranges, suggesting a highresistivity region near the surface. At sites 001 and 002, the phase significantly decreases with decreasing frequency from a few tens of hertz to $1 \mathrm{~Hz}$. On the other hand, the phase at site 004 gradually decreases compared to sites 001 and 002. This feature suggests a relatively highresistivity body at a deeper part beneath sites 001 and 002 . At site 005 , the phases are greater than $60^{\circ}$ through frequencies from $10 \mathrm{kHz}$ to $10 \mathrm{~Hz}$ for both the TE and TM modes, and the apparent resistivities of both modes decrease to 1 to $2 \Omega \mathrm{m}$ at $10 \mathrm{~Hz}$, a feature quite different from the other sites. This suggests that there is a significant change in the resistivity structure around site 005 .

Figure $3 \mathrm{~b}$ shows the same features for the Matsao-Dayou-keng area. At sites 111 and 105, the phase increases from $45^{\circ}$ to $50^{\circ}$ to $60^{\circ}$ as frequency decreases from 10 $\mathrm{kHz}$ to 10 to $20 \mathrm{~Hz}$ for both the TE and TM modes, although their phase change patterns differ slightly. Site 108 also phase change pattern similar to sites 111 and 105 . At these three sites, the phase significantly decreases to approcimately $30^{\circ}$ as frequency decreases from 10 to 20 to $1 \mathrm{~Hz}$. These features suggest a shallow conductive body and a resistive body deeper beneath the sites. At sites 109 and 110, the phase begins decreasing from a few hundred hertz, suggesting that the resistive body mentioned above could rise toward a shallower level beneath sites 109 and 110. At site 008 , the phase stays higher than $60^{\circ}$ through frequencies from $1 \mathrm{kHz}$ to several hertz, suggesting a conductive body underneath.

\section{2-D analysis}

2-D resistivity structure analyses were performed using the inversion code developed by Ogawa and Uchida (1996). This code performs smoothness-constrained 2$\mathrm{D}$ inversion based on the ABIC minimization method, where trade-off parameters between data misfit, model roughness, and static shift are estimated to minimize the misfit functional, assuming that static shifts follow Gaussian distributions. Error floors for apparent resistivity and phase were set to be $10 \%$ and $7 \%$ for the Chishinshan and Matsao-Da-you-keng areas, respectively. The resistivity structures were projected to lines A-A' and B-B' for the two areas, as shown in Figure 1. To represent the overall topographic change at each observation area, we defined the topography by averaging within $2 \mathrm{~km}$ of line A-A' for the Chishinshan area and within $1.3 \mathrm{~km}$ of line B-B' for the Matsao-Da-you-keng area. Note that the results thus obtained for the average topography do not differ much 

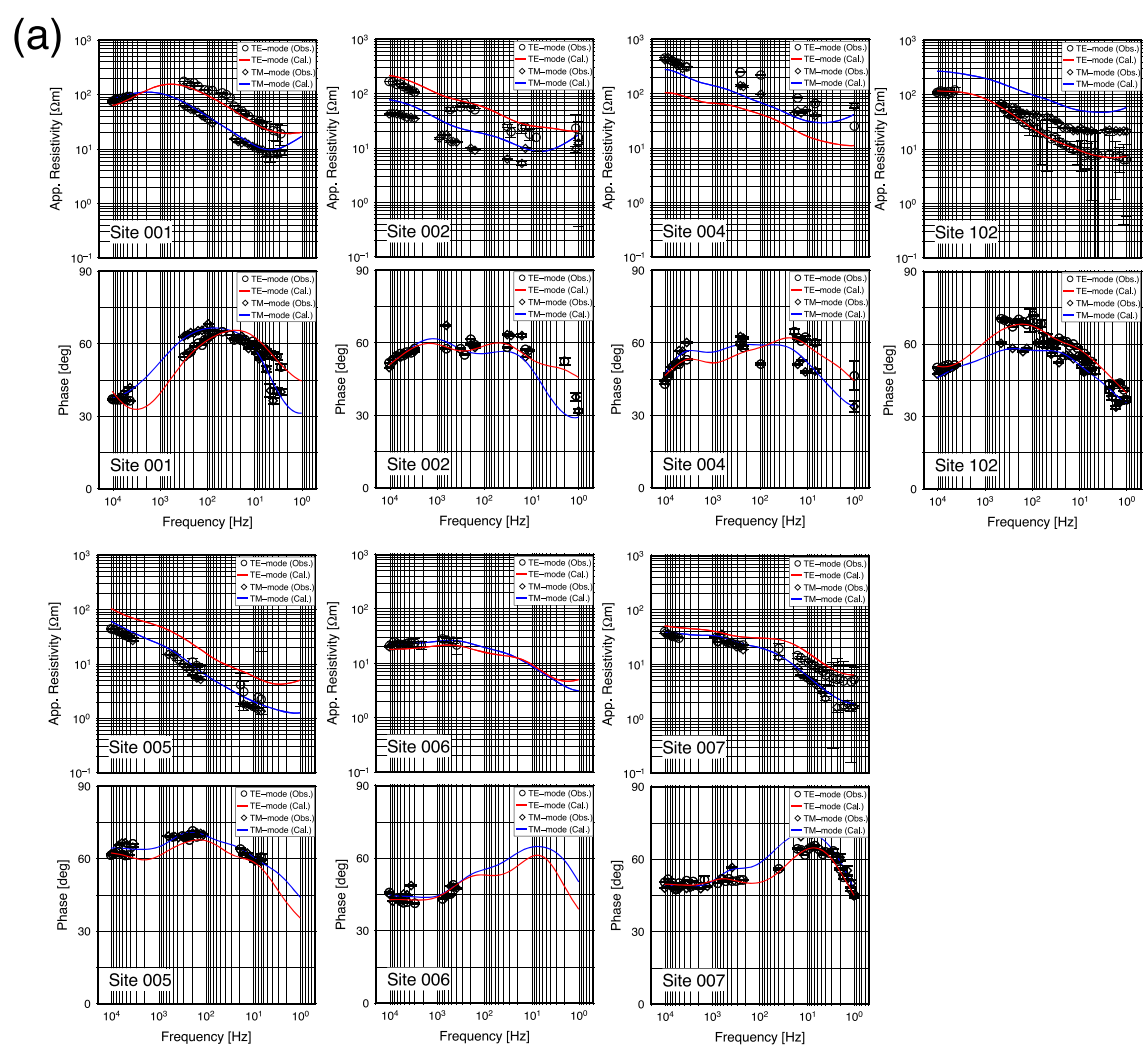

(b)
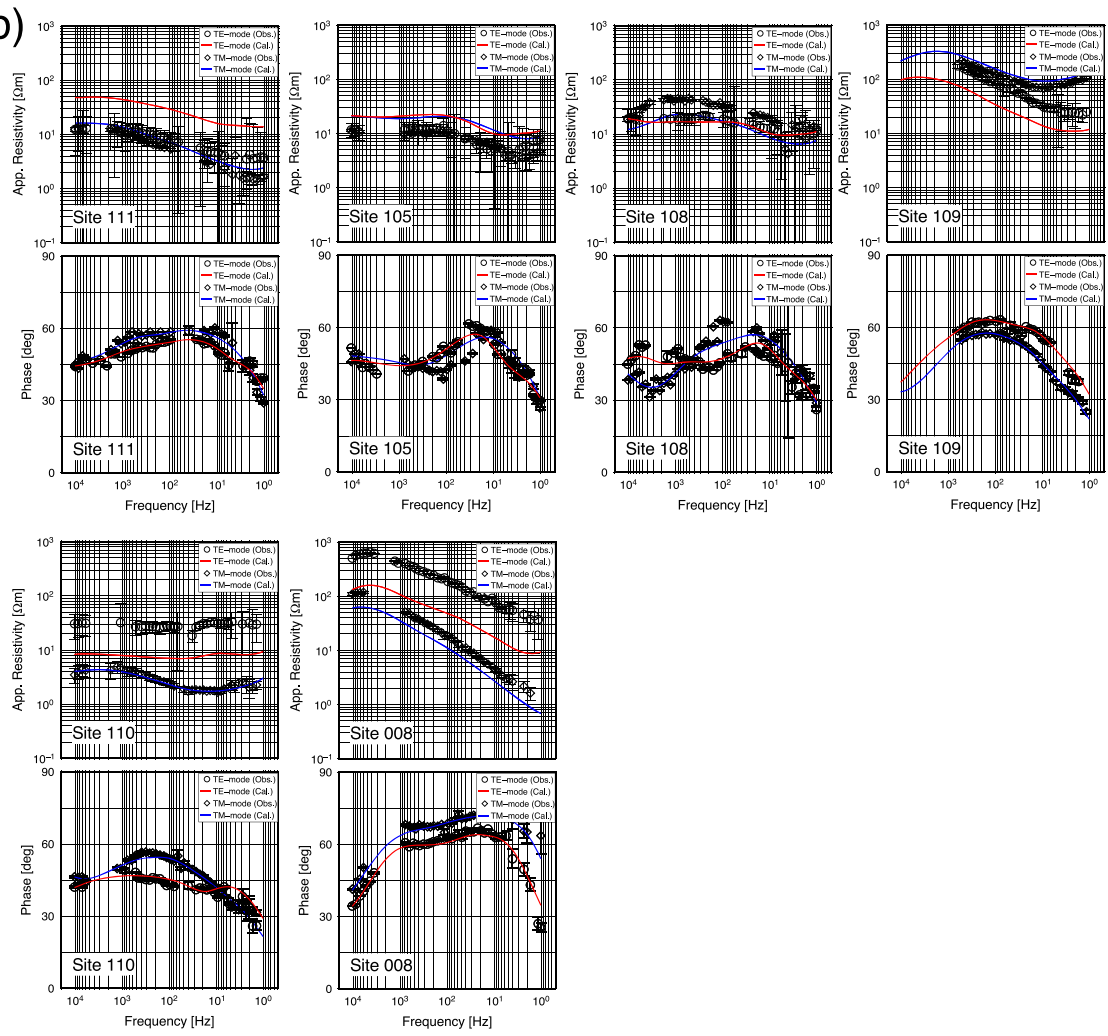

Figure 3 Sounding curves of apparent resistivity and phase for both the TM and TE modes. (a) Chishinshan area. (b) MatsaoÜDa-you-keng area. Circles and diamonds represent the data for the TE mode and TM mode respectively, obtained from observations. Red and Blue lines represent the data for the TE mode and TM mode respectively, calculated using the best-fit model. 

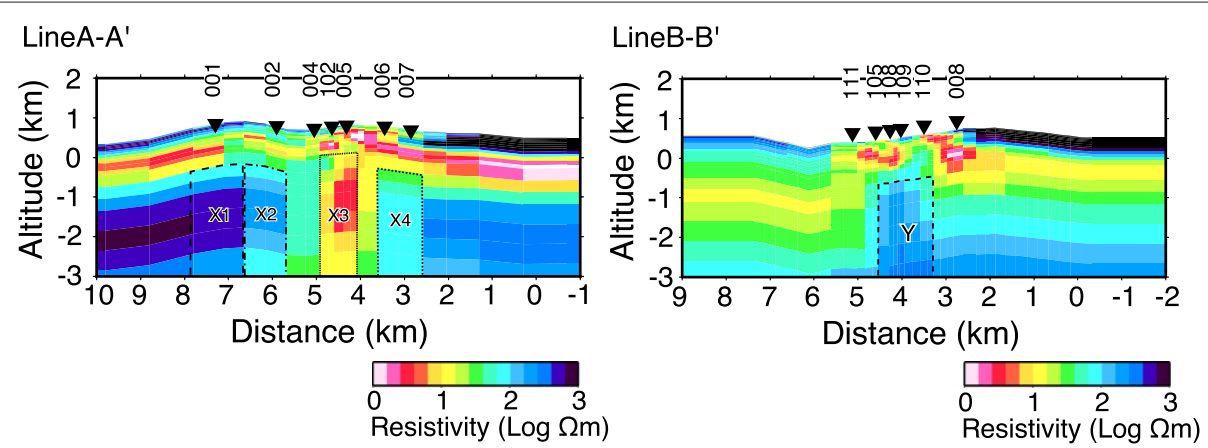

Figure 4 Best-fit models obtained from 2-D analysis. Solid inverted triangles represent observation points. Site numbers are indicated above black triangles. $\mathrm{X} 1$ to $\mathrm{X} 4$ and $\mathrm{Y}$ represent regions used for the sensitivity tests.

from those using the actual topography along $\mathrm{A}-\mathrm{A}^{\prime}$ and B-B'.

Figure 4 shows the best-fit models obtained after 42 iterations for the Chishinshan area and 31 for the MatsaoDa-you-keng area, starting from an initial model with a uniform resistivity of $100 \Omega \mathrm{m}$, with both RMS misfits of 1.02. Figure 3 shows the calculated soundings for the TE mode (red line) and TM mode (blue line). The inferred models reproduce most of the apparent resistivity and phase distributions. In the Chishinshan area, there seems to be no relation between the amount of static shift and the topographic change. The TE mode at site 004 has a relatively large static shift. Fumarolic activities do sporadically occur around site 004 in the area called Siaoyou-keng. This is characterized by a surface resistivity less than $30 \Omega \mathrm{m}$ from the VLF-MT survey (Kagiyama et al. 2010). This suggests that site 004 could have relatively strong 3-D heterogeneity near the surface, leading to the relatively large static shift. The Matsao-Da-you-keng area has a larger static shift than the Chishinshan area, presumably because most of its sites are situated amid sharp cliffs, resulting in a static shift due to the local topography (e.g., Jiracek 1990).

\section{Sensitivity tests}

Before making any interpretations on the basis of our analyses, we performed the following series of sensitivity tests:

(i) Linear sensitivity analyses based on the method of Schwalenberg et al. (2002). According to that study's authors, model sensitivity can be described as:

$$
S_{j}=\frac{1}{\Delta_{j}} \sum_{i}^{N}\left\|\frac{1}{\sigma_{i}} \frac{\partial f_{i}(\mathbf{m})}{\partial m_{j}}\right\|
$$

where $S_{j}$ is the sensitivity of grid element $j$ of size $\Delta_{j}, f_{i}(\mathbf{m})$ is the forward solution of model $\mathbf{m}, m_{j}$ is the resistivity change of grid element $j, \sigma_{i}$ is the standard deviation of the data, and $N$ is the number of elements = number of observation sites $\times$ number of frequencies $\times$ data types. This equation states that model resolution is the sum of the gradient of the forward solution to the resistivity change of a given grid element, which we normalize with regard to the standard deviation of the data, weighted by the size of each grid element. There are four types of data and forward solutions, the apparent resistivities and phases of the TE and TM modes.

Figure 5a shows the resultant model sensitivity, which decreases with depth, corresponding to the limit of the sounding frequency. The high-resistivity body situated below 1 to $1.5 \mathrm{~km}$ beneath sites 001 and 002 in the Chishinshan area has a variety of sensitivities ranging from $10^{-3}$ to $10^{-6}$, as do the resistive bodies situated below $1 \mathrm{~km}$ beneath sites 111, 105, 108, and 109 in the Matsao-Da-you-keng area. The MT method is generally less sensitive to resistive bodies because of the properties of electromagnetic waves, which can be easily absorbed by a conductor (e.g., Cagniard 1953; Vozoff 1991; Simpson and Bahr 2005). For this reason, evaluating the reliability of the resistive body was necessary.

As shown in Figure 4, a low-resistivity, column-shaped body was found below a depth of $1 \mathrm{~km}$ at sites 102 and 005 in the Chishinshan area. This structural feature is represented by the low-frequency range soundings at sites 004 , 102, and 005 (Figure 3). However, many data are missing because of their low quality, suggesting that such inverted deeper structures are not unique. It is also known that low-quality data or 2-D analysis of a 3-D situation may introduce inversion artifacts.

In order to confirm these regions with reliable sensitivity, the deeper resistive or conductive bodies shown by regions $\mathrm{X} 1$ to $\mathrm{X} 4$ and $\mathrm{Y}$ in Figures 4 and $5 \mathrm{a}$ were submitted to the following further sensitivity analysis.

(ii) Examination of changes in the sounding curves by making distinctive changes in the model.

\section{Case 1: region $X 1$ to $X 4$}

Regions X1, X2, and X4 have high resistivities with values more than $100 \Omega \mathrm{m}$. For these cases, changes in 


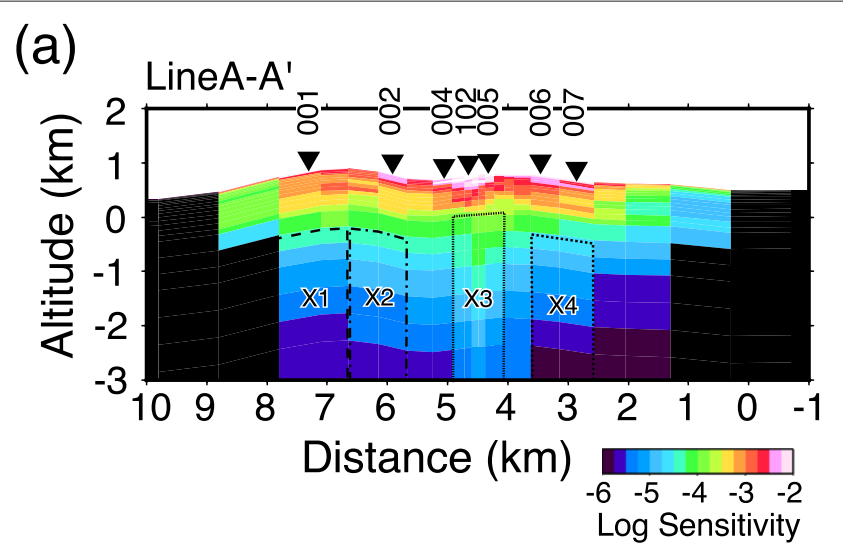

(b)

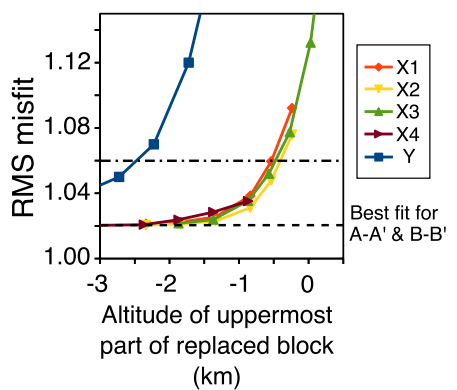

(c)

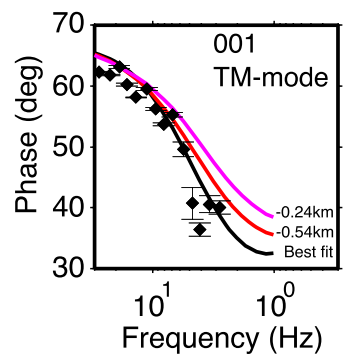

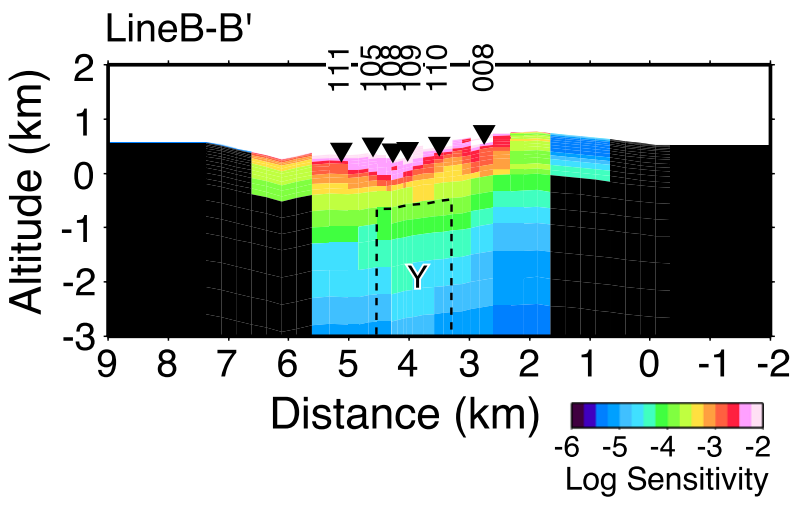

Replaced block: $Y$

(d)
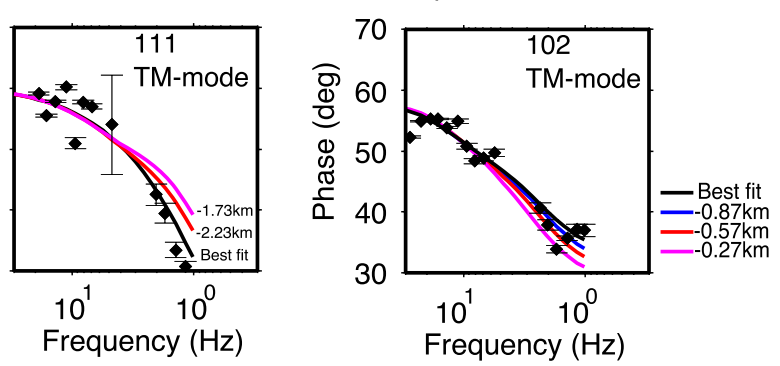

Figure 5 Sensitivity tests. (a) Results of linear sensitivity analysis. Site numbers are indicated above black triangles. (b) Variation in RMS misfits by further sensitivity analyses for each case. (c) Sensitivities of the TM phase at sites 001 and 111 by further sensitivity analysis for the cases where blocks $X 1$ and $Y$ are replaced. (d) Sensitivities of the TM phase at site 102 by further sensitivity analysis for the case where block X2 is replaced.

RMS misfits were examined by replacing the data for the regions with a conductive body. Region X3, which has low resistivities with values less than $10 \Omega \mathrm{m}$, was replaced with a resistive body. Figure $5 \mathrm{~b}$ shows the RMS misfits when a $10-\Omega \mathrm{m}$ body was substituted for $\mathrm{X} 1, \mathrm{X} 2$, and $\mathrm{X} 4$ and a $100-\Omega \mathrm{m}$ body was substituted for X3. The horizontal axis indicates the altitude of the uppermost part of the replacing body. The RMS misfits increase with the elevation of the substitute bodies, except in region $\mathrm{X} 4$ where there was no significant increase of the RMS misfit, suggesting that region $\mathrm{X} 4$ has little sensitivity. The change of TM phase at site 001 (Figure 5c) shows that the calculated sounding curve does not fit well within 3 to $7 \mathrm{~Hz}$ at an altitude of $-0.54 \mathrm{~km}$, as the RMS misfit is approximately 1.06 . This is indicated by the dotted and dashed line in Figure 5b. Thus, RMS misfits greater than 1.06 indicate significant discrepancies from the best-fit model. We thus concluded that computational blocks with sensitivities of at least $10^{-4.5}$ can be supported by the observed data.

Region X3 has relatively high sensitivities at deeper depths compared to the other regions (Figure 5a). Its RMS misfit increased significantly when the block was replaced at the same altitude as the other cases $(-0.27$ $\mathrm{km}$; Figure $5 \mathrm{~b})$. This occurred because of the unstable soundings at low frequencies at site 102 . Figure $5 \mathrm{~d}$ shows the change in the TM phase at site 102 that occurs when region X3 is replaced with a $100-\Omega \mathrm{m}$ body. Although the modified soundings show rough changes over the range of the uncertainty of the data for altitudes between $-0.87 \mathrm{~km}$ and $-0.57 \mathrm{~km}$, they are still unstable. Taking into account the changes in RMS misfits, we consider the structure beneath the shallow conductive layer at sites 004, 102, and 005 to be valid for the computational block at altitudes from -0.27 to $-0.57 \mathrm{~km}$.

\section{Case 2: region $Y$}

Region Y's resistivity is high, being more than $100 \Omega \mathrm{m}$. Figures $5 \mathrm{~b}$ and $\mathrm{c}$ show the changes in RMS misfit and the phase sensitivities of the phase when region $Y$ is replaced with a $10 \Omega \mathrm{m}$ body. As the elevation of the replacing body increases, the RMS misfit increases significantly, and the fit of the calculated to observed soundings worsens at 1 to $3 \mathrm{~Hz}$, as described in case 1 . Given this information, we consider that computational blocks with sensitivities of at least $10^{-4.5}$ can be supported.

\section{2-D resistivity structure}

Figure 6 shows the resistivity structures of the Chishinshan area (line A-A') and the Matsao-Da-you-keng area 


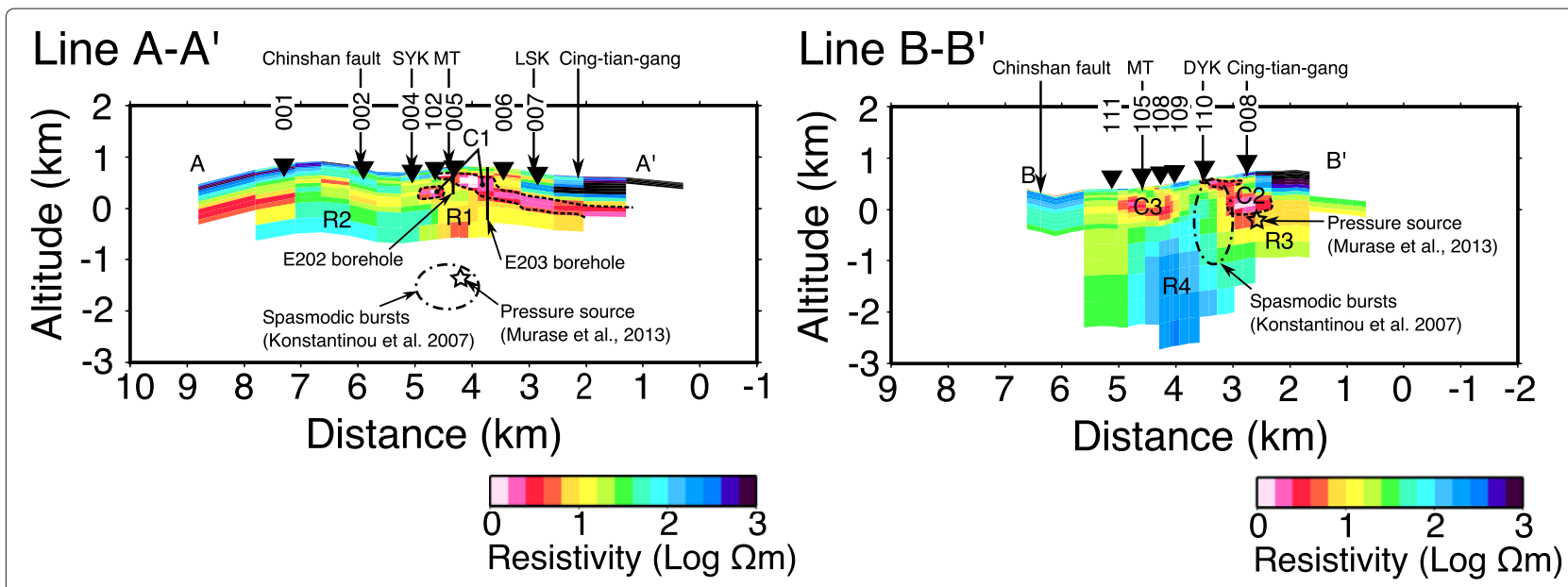

Figure 6 Resistivity structures along lines A-A' and B-B', after removal of the low-sensitivity part. Site numbers are indicated above black triangles. Locations of pressure sources (Murase et al. 2013) and spasmodic bursts (Konstantinou et al. 2007) are shown respectively as stars and ellipses in the structure along lines A-A' and B-B'. The solid lines represent the trajectories of boreholes E202 and E203 drilled by MRSO (1970).

(line B-B') after removing the low-sensitivity regions defined in the previous section.

The northern half of line $A-A^{\prime}$ has a resistive surface of several hundred to one thousand ohm meters with a thickness of one hundred to several hundreds of meters. The southern half has a surface with a resistivity of 10 to $30 \Omega \mathrm{m}$, except at its southern end, where the resistivity is greater than $100 \Omega \mathrm{m}$. These features are consistent with the results from previous electrical resistivity surveys (DC surveys) by the MRSO $(1969,1970,1971,1973)$ and VLF-MT surveys by Kagiyama et al. (2010). Two discrete conductive regions with resistivities less than $3 \Omega \mathrm{m}$ are present at depths of several hundred meters beneath Mt. Chishinshan (C1 in Figure 6). These were also suggested by the apparent resistivity distribution obtained from the MRSO DC surveys (1969, 1970, 1971, 1973).

Figure 7a shows the resistivities along borehole E203, shown in Figure 6, one of the MRSO drilling sites (1970). Red lines represent the resistivities obtained in the present study, while black represent those from well logging (MRSO 1970). The latter shows resistivities of a few $\Omega \mathrm{m}$ at depths from 200 to $670 \mathrm{~m}$ with some fluctuations, increasing to several tens of ohm meters at depths of 670 to $1,000 \mathrm{~m}$. The inferred resistivities around the borehole can reproduce the low resistivities from well logging quite well, although the inferred values for the resistive section of 670 to $1,000 \mathrm{~m}$ in depth are slightly lower than those from well logging. From these results, we determined that our method produces a reliable resistivity structure for the Chishinshan area from the surface to a depth of approximately $1 \mathrm{~km}$.

Line B-B', shown in Figure 6, has a surface with a resistivity of generally less than a few tens of ohm meters . In particular, the surface at site 110 has a resistivity of less than $3 \Omega \mathrm{m}$, corresponding to the Da-you-keng fumarolic area. There are two conductive regions at depths of a few hundred meters to $1 \mathrm{~km}$ beneath the Matsao hot spring area (C3 in Figure 6) and Cing-tian-gang (C2). They are connected to the conductive surface around the Da-youkeng fumarolic area, overlying a resistive body of about a few hundred ohm meters . Two separate conductive regions are suggested by the distribution of apparent resistivity from the MRSO DC survey $(1969,1970,1971,1973)$. Thus, by comparing the inferred results with previous work, the resistivity structure obtained along line B-B' is likewise believed to be reliable.

\section{Discussion}

This section attempts to interpret the resistivity structures obtained in this study, based mainly on reports from geothermal drillings by the MRSO (1969, 1970, 1971,1973 ) and evidence from geochemistry (Ohba et al. 2010; Ohsawa et al. 2013), seismology (Konstantinou et al. 2007), and leveling (Murase et al. 2013). For easy reference, we define the following ranges of resistivity: extremely low resistivity (less than $3 \Omega \mathrm{m}$ ), low resistivity (3 to $10 \Omega \mathrm{m}$ ), relatively low resistivity (10 to $30 \Omega \mathrm{m}$ ), relatively high resistivity ( 30 to $100 \Omega \mathrm{m}$ ), and high resistivity (greater than $100 \Omega \mathrm{m}$ ).

\section{Chishinshan area}

Low-permeability cap inferred from extremely low resistivity upper layer

As described in the previous section, the foot of Mt. Chishinshan has an extremely low resistivity layer a few hundred meters thick near the surface, as shown by $\mathrm{C} 1$ in Figure 6 . This layer corresponds roughly to a region with a temperature of $100^{\circ} \mathrm{C}$ to $200^{\circ} \mathrm{C}$, as shown in Figure $7 \mathrm{~b}$, 

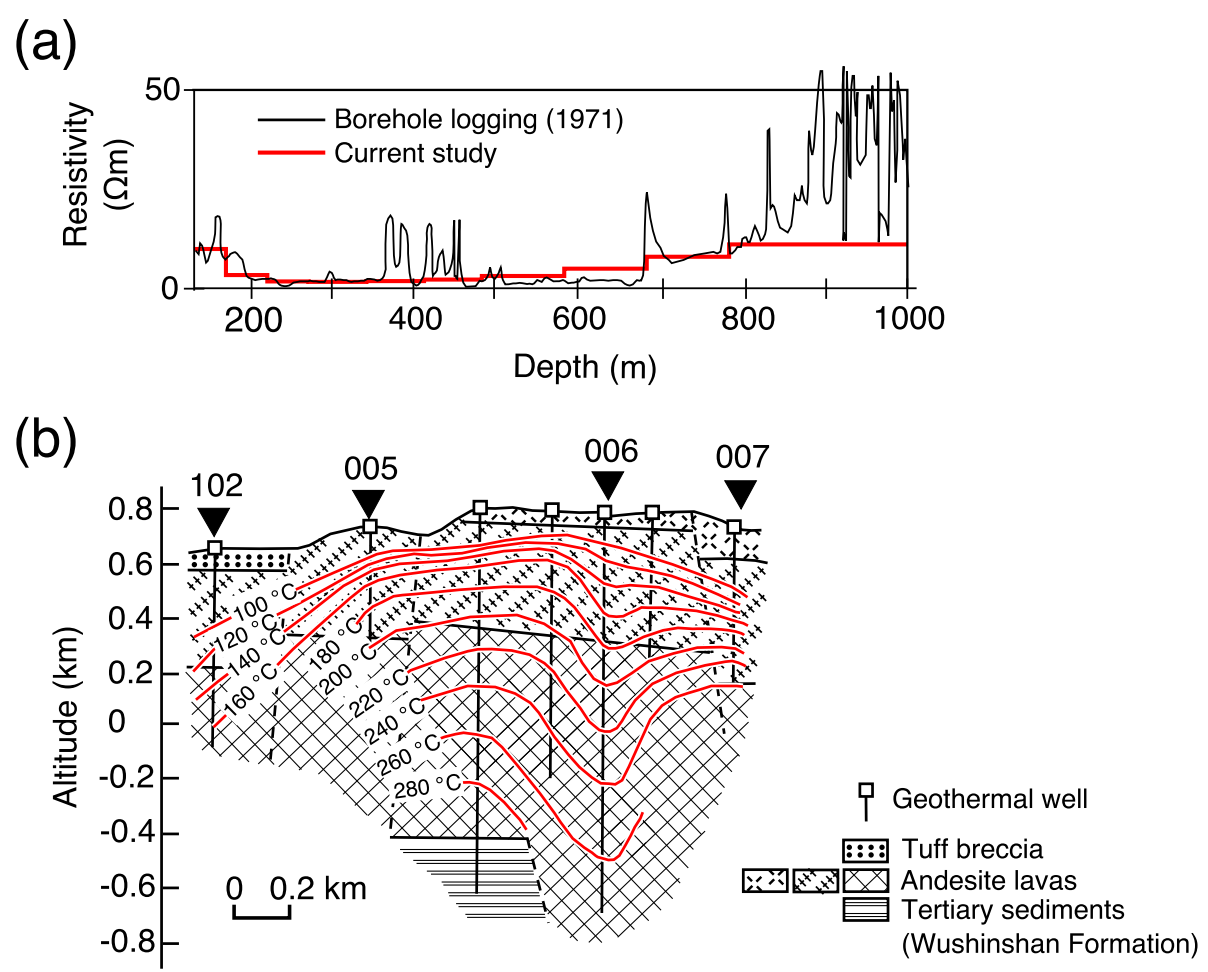

Figure 7 Comparison between inverted results and in-situ measurement. (a) Resistivities along borehole E203, shown in Figure 6. Red and black lines represent the resistivities obtained by this study and by well logging (MRSO 1970), respectively. (b) Geologic section along sites 102, 005, 006, and 007 at the foot of Mt. Chishinshan (MRSO 1973). Red lines represent the isotherm obtained from temperature logging of the boreholes (MRSO 1973). The locations of the boreholes are shown by the squares in Figure 1.

as obtained from temperature loggings (MRSO 1973). According to the drilling report, the $100^{\circ} \mathrm{C}$ to $200^{\circ} \mathrm{C}$ region is rich in smectite, but smectite is not present below depths corresponding to temperatures greater than $220^{\circ} \mathrm{C}$ (MRSO 1973). In general, smectite is stable at temperatures less than $180^{\circ} \mathrm{C}$ to $200^{\circ} \mathrm{C}$ (e.g., Pytte and Reynolds 1989; Anderson et al. 2000; Komori et al. 2013b). This significantly decreases both the resistivity and permeability of rock matrices (e.g., Ogawa et al. 1998; Revil and Cathles 1999; Revil et al. 2002; Komori et al. 2013b). Based on these earlier studies, layer $\mathrm{C} 1$ appears to be rich in smectite and could behave as a low-permeability cap to prevent hydrothermal fluids from easily discharging.

Layer $\mathrm{C} 1$ overlies the low to relatively low resistivity region $\mathrm{R} 1$. Beneath this region, there are 'spasmodic bursts' of clustered seismicity inferred by the seismological observations of Konstantinou et al. (2007) and a pressure source inferred by Murase et al. (2013)'s precise leveling surveys, as shown in Figure 6. The authors consider the seismic activity and crustal deformation to be associated with the flow of hydrothermal fluids. Unfortunately, the present study could not reveal a corresponding resistivity structure with high precision. We can, at least, consider that upwelling hydrothermal fluids, supplied from a deeper part, are maintained in region R1, covered by the low-permeability cap C1. This is a typical interpretation of resistivity structures obtained for shallow hydrothermal systems (e.g., Ogawa et al. 1998; Nurhasan et al. 2006; Komori et al. 2013a). In addition, the MRSO (1973) performed well tests at borehole E202, which reaches to R1 as shown in Figure 6 and extracted hydrothermal fluids with a steam ratio greater than $80 \%$. This suggests that region R1 is dominated by vapors. This structure is considered to extend from Mt. Chishinshan toward Leng-shuei-keng and Cing-tian-gang.

\section{Hydrothermally inactive area in the northern half of the Chishinshan area}

In contrast to the area beneath Mt. Chishinshan, the northern half of line A-A' has no extremely low-resistivity layer like layer $\mathrm{C} 1$. This suggests that there is no structural feature that confines vapor-rich fluids as described previously. Actually, there are neither fumaroles nor temperature anomalies in this area. One borehole penetrated to a depth of $200 \mathrm{~m}$ (shown by rhombus 'p' in Figure 1). It has a bottom-hole temperature almost identical to the surface temperature $\left(17^{\circ} \mathrm{C}\right.$ : CGS 2009). Based on these factors, no hydrothermal activity appears to be developed in the northern half of the Chishinshan area. 
This area does have two relatively high to high resistivity regions at the surface and at greater depths (R2). The high-resistivity surface corresponds to lava flows with little or no hydrothermal alteration (MRSO 1970; CGS 2009). MRSO (1970) reported that tertiary sediments are exposed to the surface around Beitou and Liu-huang$\mathrm{ku}$, a few kilometers southwest of this area. MRSO's comparison of the results of drilling and a DC survey in the above areas (MRSO 1969) indicates that weakly altered sediments correspond to an apparent resistivity of approximately $100 \Omega \mathrm{m}$, while strongly altered sediments show resistivities less than $10 \Omega \mathrm{m}$. This supports $\mathrm{R} 2$ as consisting of weakly altered tertiary sediments. Alternatively, R2 might be solidified igneous rocks, as suggested by the quite high resistivity of weakly altered lava observed at the surface. At a minimum, we can consider that resistive body R2 corresponds to weakly altered materials. There is also a possibility that region $\mathrm{R} 2$ might represent an extensive dry region, due to an absence of conductive fluids (e.g., Rinaldi et al. 2011), but this can be rejected based on the lack of a significant Bouguer anomaly, which is indicative of low-density material (Hsieh et al. personal communication).

\section{Da-you-keng area}

The Da-you-keng area has an intense fumarole with sulfur precipitation and hot spring water with a temperature of $100^{\circ} \mathrm{C}$ to $120^{\circ} \mathrm{C}$ (CGS 2009; Lee et al. 2005, 2008). extremely low-resistivity region, shown as $C 2$ in Figure 6, reaches approximately $1 \mathrm{~km}$ near the surface of this area, extending relatively deeper beneath Cingtian-gang. At a depth of $500 \mathrm{~m}$ beneath Cing-tian-gang, corresponding to the uppermost part of region $\mathrm{C} 2$, a temperature of $100^{\circ} \mathrm{C}$ has been recorded by a thermalmonitoring well, shown by rhombus 'q' in Figure 1 (CGS 2009). Based on considerations described in the section on the Chishinshan area, region $\mathrm{C} 2$ may correspond to a low-permeability cap due to a large amount of smectite.

The underlying low to relatively low resistivity region R3 beneath Cing-tian-gang corresponds to a pressure source inferred by Murase et al. (2013). Based on the above previous studies, hydrothermal fluids are considered to be maintained in region $\mathrm{R} 3$, and these fluids could ascend toward Da-you-keng along paths controlled by the lowpermeability cap. The ascent of fluids could induce the seismic burst events near the Da-you-ken-Cing-tian-gang area as shown in Figure 6 (Konstantinou et al. 2007). According to Ohba et al. (2010), fumarolic gases from Dayou-keng originate in as a mixture of magmatic vapors and meteoric vapors, which suggests that the hydrothermal reservoir maintains vapor-rich fluids. Therefore, we consider R3 to be dominated by vapors, like region R1 of the Chishinshan area.
This study also shows that the Da-you-keng fumarolic area has a relatively thin conductive surface, compared to the Chishinshan area. As mentioned previously, smectite composing the conductive layer is stable at temperatures of less than $180^{\circ} \mathrm{C}$ to $200^{\circ} \mathrm{C}$. The lack of a thick conductive layer is considered to be due to a high-temperature gradient, suggesting the presence of high-temperature fluids in the shallow subsurface of the fumarolic area. This is consistent with the dominance of vapor-rich fluids suggested by Ohba et al. (2010).

\section{Matsao area}

In the Matsao area, hot spring water with a temperature of $30^{\circ} \mathrm{C}$ to $50^{\circ} \mathrm{C}$ discharges CGS 2009; Ohsawa et al. 2013), and there is no fumarolic area around the AMT observation points. According to sulfur isotope analysis of hot spring water from the TVG (Ohsawa et al. 2013), hot springs in the Matsao area are formed by mixing meteoric water with vapors separated from deep magmatic hydrothermal fluids, which then flow at shallow depths from Mt. Chishinshan along its topography. The Matsao area has an upper region with resistivities of less than $10 \Omega \mathrm{m}$ at depths of 0 to $1 \mathrm{~km}$, shown in $\mathrm{C} 3$, and an underlying high-resistivity region R4. Based on Ohsawa et al. (2013), region C3 could correspond to the shallow flow system of the Matsao area's hydrothermal fluid. Region R4 could correspond to less-altered materials, such as sediments or solidified igneous rocks, as described in the previous section. This is supported by the lack of a significant Bouguer anomaly around this area (Hsieh et al. personal communication).

\section{Inferred hydrothermal system of the TVG and its implication for potential volcanic hazards}

We discussed the relation between the resistivity structure and other geophysical and geochemical data above. On basis of the insights thus obtained, in this section, we propose a better description of the hydrothermal system of the TVG, as shown in Figure 8. Beneath Mt. Chishinshan, vapor-rich hydrothermal fluids are supplied from the deeper part. The fluids are maintained below the clay-rich, low-permeability cap, extending horizontally beneath the foot of Mt. Chishinshan. Some vapors are discharged through breaks or along the end of the clay-rich layer, developing fumarolic areas like Siao-youkeng. Further on, the vapor mixes with groundwater at the shallow subsurface, forming so-called 'steam-heated thermal waters', which develop the shallow flow system of hydrothermal fluids in the Matsao area. The fumaroles at Da-you-keng area, on the other hand, may be supplied from the deeper part beneath Cing-tian-gang and vaporrich fluids maintained in the region, covered by a clay-rich cap. 


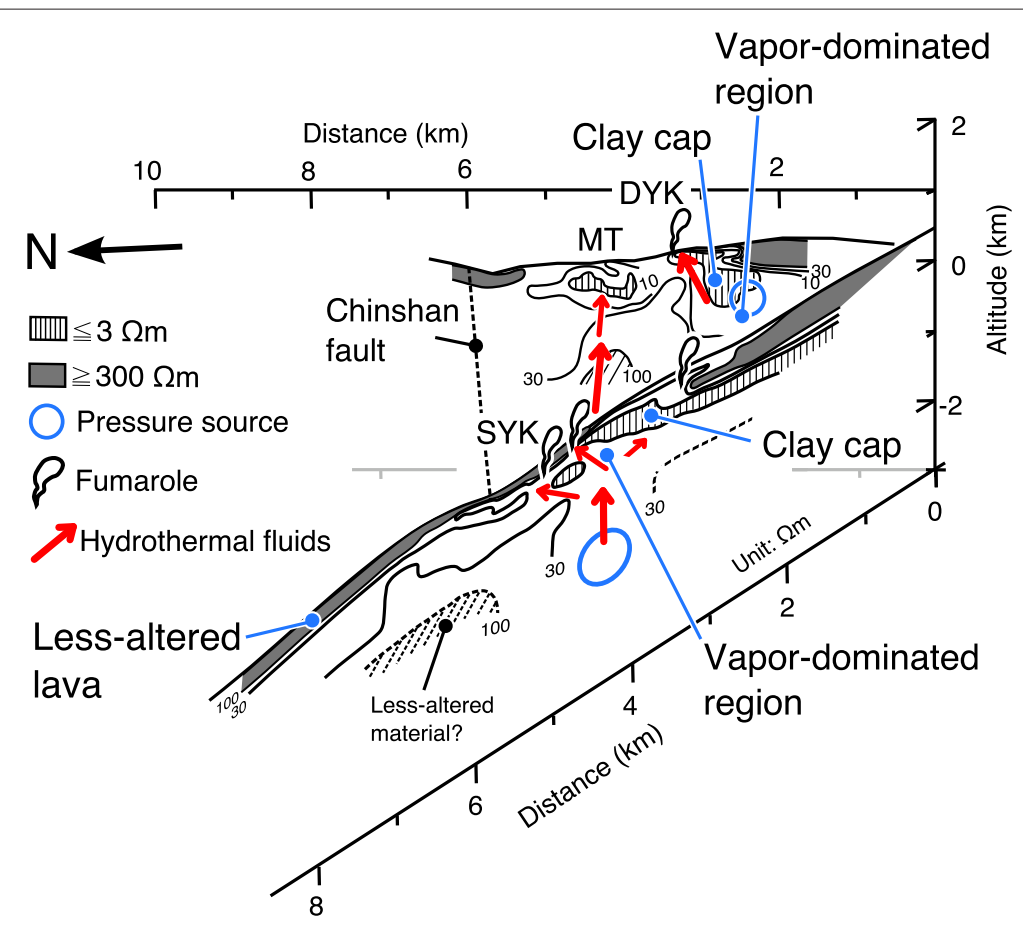

Figure 8 Conceptual model of the hydrothermal system of the Tatun Volcano Group. As inferred by interpretation of the resistivity structure and other geochemical and geophysical evidence.

We estimate that an extensive vapor-bearing region could be situated beneath the foot of Mt. Chishinshan, Da-you-keng, and Cing-tian-gang, suggesting the potential for future phreatic explosions caused by a rapid increases in the internal fluid pressure due to intense injection of volcanic fluids (e.g., Voight and Elsworth 1997; Nakada et al. 1999). A phreatic eruption actually occurred as the latest activity at Mt. Chishinshan circa 6,000 years ago (Belousov et al. 2010). The data also suggest that the vapor may have been maintained for several thousand years. These factors point to the need for future work to detect signals related to phreatic explosions. Precursors might be detected by the following ongoing observations: temporal variations of chemical and isotopic composition (Lee et al. 2008), microgravity changes (Hwang et al. 2012), changes in precise leveling surveys (Murase et al. 2013), and temporal changes in tiltmeter readings (Lin, personal communication).

This study, however, did not reveal magmas suggested by a deeply distributed aseismic region as in Konstantinou et al. (2007), and their interrelation with the two pressure sources, due to a lack of data with low-frequency ranges. In the future, broadband MT surveys will reveal the deeper structural features to further elucidate the conditions from the viewpoint of hydrothermal fluid flow (i.e., Aizawa et al. 2013).

\section{Conclusions}

This study revealed the resistivity structure associated with hydrothermal activity in the Tatun Volcano Group using AMT surveys to investigate the present state of this system. The structure obtained here can be consistently explained by hot spring water and fumarolic gas formation processes as indicated by geochemical work. Its association with seismicity and pressure sources supports the presence of paths of hydrothermal fluid flow. This study also inferred the presence of an extensive vapor-bearing region covered by a low-permeability cap beneath Mt. Chishinshan and Da-you-keng-Cing-tian-gang. This suggests the possibility of future phreatic explosions around the area. The results indicate that an integrated conceptual model for the hydrothermal system at the TVG can provide reliable constraints for its potential volcanic hazards.

\section{Competing interests}

This study was partly supported by Grants-in-Aid for Scientific Research (No. 21403003 and No. 23310120, T. Kagiyama) from the Ministry of Education, Culture, Sports, Science and Technology of Japan, and by a thematic research program application (AS-101-TP-A05, B.F. Chao) from the Academia Sinica, Taiwan. The authors declare that they have no competing interests.

\section{Authors' contributions}

SK organized the AMT surveys in 2012, participated in the surveys in the Mt. Chishinshan area, and carried out all of the data analyses. MU organized the surveys in 2011 and dealt with instrument logistics. RY and WK participated in the surveys in 2011 and were involved in interpreting the inverted results. RY 
was also involved with the data processing. TK, $\mathrm{HI}$, and HTC participated in the surveys in 2012 and were involved in interpreting the inverted results. CHC and BFC arranged the entire survey plan in cooperation with Yanminshan National Park, and contributed to improving the manuscript. All authors have read and approved the final manuscript.

\section{Acknowledgments}

We would like to thank Yangmingshan National Park for arranging the surveys and M. Murase (Nihon University) for providing data about leveling surveys. We also thank Y.H. Lee, R. Sih, G.S.K. Ma, C.C. Lin, W. Minju (Academia Sinica), P. Pong (National Taiwan University), S. Yoshikawa, T. Asano, and N. Tokumoto (Kyoto Univ.) for supporting the observations. We thank the Central Geological Survey for providing data about the thermal monitoring project. We appreciate T. Lee, T. F. Yui, D. C. Lee, K. L. Wang, Y lizuka, C. Y. Chen, C. H. Lin, X. E. Lei (Academia Sinica), C. Hwang (National Chiao Tung University), T. F. Yang, S.R. Song (National Taiwan University), K. Takemura, S. Ohsawa, and K. Matsuo (Kyoto University) for their valuable discussions. We also appreciate G. Zellmer (Massey University) for valuable comments and for improving the manuscript. The manuscript was critically reviewed by two anonymous reviewers. We appreciate H. Shimizu for the editorial support. Some figures were made using the GMT program (Wessel and Smith 1998).

\section{Author details}

${ }^{1}$ Institute of Earth Sciences, Academia Sinica, 128 Academia Road, Section 2, Nankang, Taipei 115, Taiwan. ${ }^{2}$ Aso Volcanological Laboratory, Kyoto University, Minamiaso, Kumamoto 869-1404, Japan. ${ }^{3}$ Institute of Oceanography, National Taiwan University, No. 1, Sec. 4, Roosevelt Road, Taipei 10617, Taiwan. ${ }^{4}$ Research Center for Earthquake Prediction, Disaster Prevention Research Institute, Kyoto University, Gokasho, Uji, Kyoto 611-0011, Japan. ${ }^{5}$ Volcanic Fluid Research Center, Tokyo Institute of Technology, 2-12-1 Ookayama, Meguro, Tokyo 152-8551, Japan. ${ }^{6}$ Present address: Geological Survey of Japan (GSJ), AIST, Central 7, 1-1-1 Higashi, Tsukuba, Ibaraki 305-8567, Japan.

\section{Received: 12 February 2014 Accepted: 2 September 2014 Published online: 11 October 2014}

\section{References}

Aizawa K, Ogawa Y, Ishido T (2009) Groundwater flow and hydrothermal systems within volcanic edifices: delineation by electric self-potential and magnetotellurics. J Geophys Res 114(B1):B01208. doi:10.1029/2008JB005910

Aizawa K, Koyama T, Hase H, Uyeshima M, Kanda W, Utsugi M, Yoshimura R, Yamaya Y, Hashimoto T, Yamazaki K, Komatsu S, Watanabe A, Miyakawa K, Ogawa Y (2013) Three-dimensional resistivity structure and magma plumbing system of the Kirishima Volcanoes as inferred from broadband magnetotelluric data. J Geophys Res 119:198-215. doi:10.1002/2013JB010682

Anderson E, Crosby D, Ussher G (2000) Bull's-eye!-simple resistivity imaging to reliably locate the geothermal reservoir. In: Proceedings of the world geothermal congress 2000. Beppu-Morioka

Belousov A, Belousova M, Chen C-H, Zellmer GF (2010) Deposits, character and timing of recent eruptions and gravitational collapses in Tatun Volcanic Group, Northern Taiwan: Hazard-related issues. J Volcanol Geotherm Res 191:205-221. doi:10.1016/j.jvolgeores.2010.02.001

Bibby HM, Caldwell TG, Brown C (2005) Determinable and non-determinable parameters of galvanic distortion in magnetotellurics. Geophys I Int 163:915-930. doi:10.1111/j.1365-246X.2005.02779.x

Cagniard L (1953) Basic theory of the magnetotelluric method of geophysical prospecting. Geophysics 18:605-635. doi:10.1190/1.1437915

Caldwell TG, Bibby HM, Brown C (2004) The magnetotelluric phase tensor. Geophys J Int 158:457-469. doi:10.1111/j.1365-246X.2004.02281.X

Central Geological Survey (CGS) (2009) 2nd period of investigation and monitoring of particular geological hazard at Taipei district: investigation and monitoring of geological hazard and volcanic activity (2/4). Central Geological Survey, Taipei (in Chinese)

Chang C-P, Chang T-Y, Angelier J, Kao H, Lee J-C, Yu S-B (2003) Strain and stress field in Taiwan oblique convergent system: constraints from GPS observation and tectonic data. Earth Planet Sci Lett 214:115-127. doi:10.1016/S0012-821X(03)00360-1

Chen C-H (1970) Geology and geothermal power potential of the Tatun volcanic region. Geothermics 2:1134-1143. http://dx.doi.org/10.1016/ 0375-6505(70)90425-6
Chen C-S (2009) Investigation of potential magma chambers beneath the Tatun volcanic area: preliminary results of magnetotelluric survey. Journal of National Park 19:1-10. (in Chinese with English abstract)

Chen C-H, Lin S-B (2002) Eruptions younger than 20 ka of the Tatun Volcano Group as viewed from the sediments of the Sungshan Formation in Taipei Basin. West Pac Earth Sci 2:191-204

Chen C-H, Wu Y-J (1971) Volcanic geology of the Tatun geothermal area, northern Taiwan. Proc Geological Soc China 14:5-20

Chen C-S, Chen C-C, Chou K (1998) Deep electrical structure of Taiwan as inferred from magnetotelluric observations. Terr Atmos Ocean Sci 9:51-68

Chen C-T, Lee J-C, Chan Y-C, Lu C-Y (2010) Growth normal faulting at the western edge of the metropolitan Taipei basin since the Last Glacial Maximum, northern Taiwan. Terr Atmos Ocean Sci 21:409-428. doi:10.3319/TAO.2009.11.13.01(TH)

Gamble TD, Goubau WM, Clarke J (1979) Magnetotellurics with a remote magnetic reference. Geophysics 44:53-68. doi:10.1190/1.1440923

Hwang C, Chao B, Chen C-C, Lee C-W, Hsieh W-C, Huang J-F, Kao R (2012) Static and time-varying gravity observations at the Tatun Volcano Group in northern Taiwan. In: Abstracts of AOGS-AGU (WPGM) joint assembly. Resorts world convention centre, Sentosa Island

Jiracek GR (1990) Near-surface and topographic distortions in electromagnetic induction. Surv Geophys 11:163-203

Juang W-S (1993) Diversity and origin of quaternary basaltic magma series in northern Taiwan. Bull Natl Museum Nat Sci 4:125-165

Kagiyama T, Utsugi M, Chen C-H, Miyabuchi Y (2010) Conductivity distribution of the surface layer around Tatun Volcanic group, Taiwan. In: Abstracts of Japan geoscience union meeting 2010, Makuhari Messe international conference hall, Chiba

Kanda W, Tanaka Y, Utsugi M, Takakura S, Hashimoto T, Inoue H (2008) A preparation zone for volcanic explosions beneath Naka-dake crater, Aso volcano, as inferred from magnetotelluric surveys. J Volcanol Geotherm Res 178(1):32-45. doi:10.1016/j.jvolgeores.2008.01.022

Komori S, Kagiyama T, Hoshizumi H, Takakura S, Mimura M (2010) Vertical mapping of hydrothermal fluids and alteration from bulk conductivity: simple interpretation on the USDP-1 site, Unzen Volcano, SW Japan. J Volcanol Geotherm Res 198:339-347. doi:10.1016/j.jvolgeores.2010.09.019

Komori S, Kagiyama T, Utsugi M, Inoue H, Azuhata I (2013a) Two-dimensional resistivity structure of Unzen Volcano by AMT and MT surveys. Earth Planets Space 65:759-766. doi:10.5047/eps.2012.10.005

Komori S, Kagiyama T, Takakura S, Ohsawa S, Mimura M, Mogi T (2013b) Effect of the hydrothermal alteration on the surface conductivity of rock matrix: comparative study between relatively-high and low temperature hydrothermal systems. J Volcanol Geotherm Res 264:164-171. doi:10.1016/j.jvolgeores.2013.08.009

Konstantinou KI, Lin C-H, Liang W-T (2007) Seismicity characteristics of a potentially active quaternary volcano: The Tatun Volcano Group, northern Taiwan. J Volcanol Geotherm Res 160:300-318. doi:10.1016/j.jvolgeores.2006.09.009

Konstantinou KI, Lin C-H, Liang W-T, Chan Y-C (2009) Seismogenic stress field beneath the Tatun Volcano Group, northern Taiwan. J Volcanol Geotherm Res 187:261-271. doi:10.1016/j.jvolgeores.2009.09.011

Lee H-F, Yang TF, Lan T-F, Song S-R, Tsao S (2005) Fumarolic gas composition of the Tatun Volcano Group, northern Taiwan. Terr Atmos Ocean Sci 16:843-864

Lee H-F, Yang TF, Lan T-F, Chen C-H, Song S-R, Tsao S (2008) Temporal variations of gas compositions of fumaroles in the Tatun Volcano Group, northern Taiwan. J Volcanol Geotherm Res 178:624-635. doi:10.1016/j.jvolgeores.2008.06.005

Lin C-H, Konstantinou Kl, Liang W-T, Pu H-C, Lin Y-M, You S-H, Huang Y-P (2005) Preliminary analysis of volcanoseismic signals recorded at the Tatun Volcano Group, northern Taiwan. Geophys Res Lett 32:L10313. doi:10.1029/2005GL022861

Lin C-H, Yang TF, Leu P-L, Chang W-Y (2012) Establishment of Taiwan Volcano Observatory at Tatun. In: Abstracts of AOGS-AGU (WPGM) joint assembly. Resorts world convention centre, Sentosa Island

Liu C-M, Song S-R, Chen Y-L, Tsao S (2011) Characteristics and origins of hot springs in the Tatun Volcano Group in northern Taiwan. Terr Atmos Ocean Sci 22:475-489. doi:10.3319/TAO.2011.05.25.01(TT)

Mining Research and Service Organization (MRSO) (1969) MRSO Report 90: the geothermal exploration of the, Tatun Volcano Group (I). Mining Research and Service Organization, Taipei (in Chinese) 
Mining Research and Service Organization (MRSO) (1970) MRSO Report 102: the geothermal exploration of the Tatun Volcano Group (II). Mining Research and Service Organization, Taipei (in Chinese)

Mining Research and Service Organization (MRSO) (1971) MRSO Report 111: the geothermal exploration of the, Tatun Volcano Group (III). Mining Research and Service Organization, Taipei (in Chinese)

Mining Research and Service Organization (MRSO) (1973) MRSO Report 126: the geothermal exploration of the, Tatun Volcano Group (IV). Mining Research and Service Organization, Taipei (in Chinese)

Murase M, Lin C-H, Kimata F, Mori H, Suzuki A (2013) Estimated pressure source and vertical deformation in Tatun volcano group, Taiwan, detected by precise leveling during 2006-2013. In: Abstracts of IAVCEI 2013 scientific assembly, Kagoshima prefectural citizens exchange center \& Kagoshima citizens social support plaza, Kagoshima

Nakada S, Shimizu H, Ohta K (1999) Overview of the 1990-1995 eruption at Unzen volcano. J Volcanol Geotherm Res 89:1-22. http://dx.doi.org/10. 1016/S0377-0273(98)00118-8

Nurhasan, Ogawa Y, Ujihara N, Tank SB, Honkura Y, Onizawa S, Mori T, Makino M (2006) Two electrical conductors beneath Kusatsu-Shirane volcano, Japan, imaged by audiomagnetotellurics, and their implications for the hydrothermal system. Earth Planets Space 58: 1053-1059

Ogawa Y, Uchida T (1996) A two-dimensional magnetotelluric inversion assuming Gaussian static shift. Geophys I Int 126:69-76. doi:10.1111/j.1365-246X.1996.tb05267.x

Ogawa Y, Matsushima N, Oshima H, Takakura S, Utsugi M, Hirano K, Igarashi M, Doi T (1998) A resistivity cross-section of Usu volcano, Hokkaido, Japan, by audiomagnetotellurics soundings. Earth Planets Space 50:339-346

Ohba T, Sawa T, Taira N, Yang TF, Lee H-F, Lan T-F, Ohwada M, Morikawa N, Kazahaya K (2010) Magmatic fluids of Tatun volcanic group, Taiwan. Appl Geochem 25:513-523. http://dx.doi.org/10.1016/j.apgeochem.2010.01.009

Ohsawa S, Lee H-F, Liang B, Komori S, Chen C-H, Kagiyama T (2013) Geochemical characteristics and origins of acid hot spring waters in Tatun Volcanic Group, Taiwan. J Hot Spring Sci 62:282-293. (in Japanese with English abstract)

Pytte AM, Reynolds RC (1989) The thermal transformation of smectite to illite. In: Naeser ND, McCulloh TH (eds) Thermal history of Sedimentary Basins: Methods and Case Histories. Springer-Verlag, New York, pp 133-140

Revil A, Cathles III LM (1999) Permeability of shaly sands. Water Resour Res 35(3):651-662. doi:10.1029/98WR02700

Revil A, Cathles III LM, Losh S (1998) Electrical conductivity in shaly sands with geophysical applications. J Geophys Res 103(B10):23925-23936. doi:10.1029/98JB02125

Revil A, Hermitte D, Spangenberg E, Cochemé JJ (2002) Electrical properties of zeolitized volcaniclastic materials. J Geophys Res 107(B8):2168. doi:10.1029/2001JB000599

Revil A, Finizola A, Ricci T, Delcher E, Peltier A, Barde-Cabusson S, Avard G, Bailly T, Bennati L, Byrdina S, Colonge J, Di Gangi F, Douillet G, Lupi M, Letort J, Tsang Hin Sun E (2011) Hydrogeology of Stromboli volcano, Aeolian Islands (Italy) from the interpretation of resistivity tomograms, self-potential, soil temperature and soil $\mathrm{CO}_{2}$ concentration measurements. Geophys J Int 186:1078-1094. doi:10.1111/j.1365-246X.2011.05112.x

Rinaldi AP, Todesco M, Vandemeulebrouck J, Revil A, Bonafede M (2011) Electrical conductivity, ground displacement, gravity changes, and gas flow at Solfatara crater (Campi Flegrei caldera, Italy): results from numerical modeling. J Volcanol Geotherm Res 207:93-105. doi:10.1016/j.jvolgeores.2011.07.008

Rontogianni S, Konstantinou Kl, Lin C-H (2012) Multi-parametric investigation of the volcano-hydrothermal system at Tatun Volcano Group, Northern Taiwan. Nat Hazards Earth Syst Sci 12:2259-2270. doi:10.5194/nhess-12-2259-2012

Schwalenberg K, Rath V, Haak V (2002) Sensitivity studies applied to a two-dimensional resistivity model from the Central Andes. Geophys I Int 150:673-686. doi:10.1046/j.1365-246X.2002.01734.x

Shyu JBH, Sieh K, Chen Y-G, Liu C-S (2005) Neotectonic architecture of Taiwan and its implications for future large earthquakes. I Geophys Res 110:B08402. doi:10.1029/2004JB003251

Simpson F, Bahr K (2005) Practical magnetotellurics. Cambridge University Press, Cambridge

Tsai Y-W, Song S-R, Chen H-F, Li S-F, Lo C-H, Lo W, Tsao S (2010) Volcanic stratigraphy and potential hazards of the Chihsingshan volcano subgroup in the Tatun Volcano Group, northern Taiwan. Terr Atmos Ocean Sci 21:587-598. doi:10.3319/TAO.2010.02.22.03(TH)

Tsao S (1994) K-Ar age determination of volcanic rocks from the Tatun Volcano Group. Bull Central Geological Surv 9:137-154. (in Chinese)

Utsugi M, Kagiyama T, Chen C-H, Kanda W, Yoshimura R, Asano T, Tokumoto N, Inoue H, Yoshikawa S (2012) Audio frequency magneto-telluric survey on Tatun Volcanic Group, Taiwan In: Abstracts of Japan geoscience union meeting 2012, Makuhari Messe international conference hall, Chiba

Voight B, Elsworth D (1997) Failure of volcano slopes. Géotechnique 47:1-31

Vozoff K (1991) The magnetotelluric method. In: Nabighian MN (ed) Electromagnetic Methods in Applied Geophysics, Society of Exploration Geophysicists, Oklahoma, pp 641-711

Waxman MH, Smits LM (1968) Electrical conductivities in oil-bearing shaly sands. Soc Pet Eng J 8:107-122

Wang W-H, Chen C-H (1990) The volcanology and fission track age dating of pyroclastic deposits in Tatun Volcano Group, northern Taiwan. Acta Geological Taiwan 28:1-30

Wang K-L, Chung S-L, Chen C-H, Shinjo R, Yang TF, Chen C-H (1999) Post-collisional magmatism around northern Taiwan and its relation with opening of the Okinawa Trough. Tectonophysics 308:363-376

Wen H-Y, Yang TF, Lan T-F, Lee H-F, Lin C-H (2013) Spatial and temporal variations of soil $\mathrm{CO} 2$ flux in geothermal areas of the Tatun Volcano Group, Northern Taiwan. In: Abstracts of IAVCEI 2013 scientific assembly, Kagoshima prefectural citizens exchange center \& Kagoshima citizens social support plaza, Kagoshima

Wessel P, Smith WHF (1998) New, improved version of generic mapping tools released. Eos Trans AGU 79(47):579

Wu C-C, Cheng C-S, Lee M-Y, Hong C-H (2009) Numerical simulation of volcanic ash dispersal and fallout from Datun volcano and Kuei-shan-tao by using PUFF model. Meteorol Bull 48:83-99. (in Chinese with English abstract)

Yang TF, Sano Y, Song S-R (1999) ${ }^{3} \mathrm{He} /{ }^{4} \mathrm{He}$ ratios of fumaroles and bubbling gases of hot springs in Tatun Volcano Group, North Taiwan. II Nuovo Cimento C 22:281-286

Yang TF, Chen C-H, Tien R-L, Song S-R, Liu T-K (2003) Remnant magmatic activity in the Coastal Range of East Taiwan after arc-continent collision: fission-track data and ${ }^{3} \mathrm{He} /{ }^{4} \mathrm{He}$ ratio evidence. Radiation Measurements 36:343-349

doi:10.1186/s40645-014-0020-7

Cite this article as: Komori et al.: Hydrothermal system in the Tatun Volcano Group, northern Taiwan, inferred from crustal resistivity structure by audio-magnetotellurics. Progress in Earth and Planetary Science 2014 1:20.

\section{Submit your manuscript to a SpringerOpen ${ }^{\circ}$ journal and benefit from:}

- Convenient online submission

- Rigorous peer review

- Immediate publication on acceptance

- Open access: articles freely available online

- High visibility within the field

- Retaining the copyright to your article

Submit your next manuscript at springeropen.com 